\title{
O percurso teórico e empírico do GT Trabalho e Educação: uma análise para debate
}

\author{
Eunice Trein e Maria Ciavatta
}

Universidade Federal Fluminense, Faculdade de Educação

\section{Introdução}

O que distingue, basicamente, um grupo de trabalho é a atividade coletiva em torno de certos objetivos comuns. O GT Trabalho e Educação da ANPEd caracteriza-se como um grupo de pesquisadores dessa área de estudos, tendo em vista a natureza da entidade a que pertence. Não seria um grupo de pesquisa em senso estrito, porque seus participantes não pesquisam, necessariamente, juntos. O GT Trabalho e Educação funciona como fórum de debates em torno de uma temática comum: as relações que se estabelecem entre o mundo do trabalho e a educação, nelas cabendo formação profissional, formação sindical, reestruturação produtiva, organização e gestão do trabalho, trabalho e escolaridade, subjetividade e trabalho etc.

Do tratamento desses temas participam pesquisadores juniors e seniors de muitas instituições, trazendo à discussão suas pesquisas, dissertações de mestrado e teses de doutorado. Pode-se inferir daí a grande heterogeneidade de idéias e de procedimentos que permeiam os trabalhos que são selecionados pelo Comitê Científico para apresentação pelo mérito, se- gundo os critérios de "relevância e pertinência do trabalho para a discussão em sua área de pesquisa", "coerência e consistência argumentativa na formulação do problema, no desenvolvimento do trabalho", e "interlocução com a produção do conhecimento na área" (ANPEd, 2002).

No entanto, há uma questão recorrente: a preocupação teórico-metodológica, que não é única, porque o GT preserva o espaço plural de discussão, mas, para a compreensão da área e de seus problemas em profundidade, é fundamental a visão da realidade e da história como produção social da existência humana. Em documento elaborado após um encontro de pesquisadores da GT, patrocinado pelo CNPq em 1986, Kuenzer registra "a necessidade de desenvolver o corpo teórico da área, através de um concentrado esforço de reflexão sobre os fundamentos teórico-metodológicos da relação entre trabalho e educação, atentando para os perigos da manipulação de conceitos gerais como se fossem uma substantividade própria, independentemente de tempo e lugar" (1987, p. 93). Afirmava-se que "a única alternativa que se coloca como válida para superar um tratamento apenas ideológico das questões é 
compreendê-las em sua situação histórica concreta; neste sentido, a constituição de um corpo teórico para o exame da relação trabalho e educação implica a reconstrução histórica como aspecto fundamental dessa reflexão" (Kuenzer, 1987).

Essa base teórica pautada no materialismo histórico segundo Marx traz consigo outro traço distintivo do GT: a visão política centrada no compromisso com a transformação das formas de exploração e amesquinhamento do ser humano, geradas pela produção e pela sociabilidade do capital. Tem prevalecido, contudo, o diálogo e o confronto com autores que questionam o marxismo ou que trazem contribuições analíticas orientadas para temas emergentes no contexto das transformações do último século, tais como a sociedade de consumo, a comunicação, a subjetividade, a presença da imagem e o ideário pós-moderno.

A relação entre o trabalho e a educação é um tema tratado desde o século passado, tanto pela economia política burguesa quanto pela marxista. No Brasil, até os anos de 1970, predominavam os estudos ligados à economia da educação e à formação profissional e técnica. Com a redemocratização do país em curso nos anos de 1980, a tentativa de construção de um novo projeto hegemônico e a afirmação de alguns cursos de pós-graduação em educação rumo a uma visão crítica e dialética, o tema trabalho e educação aparece vinculado à superação do autoritarismo e comprometido com as lutas dos trabalhadores por maior participação política e econômica.

A partir de então, as pesquisas passaram a buscar "a compreensão dos processos pedagógicos escolares e não-escolares a partir do mundo do trabalho, tomando-se o método da economia política como diretriz para a construção do conhecimento" (Kuenzer, 1998, p. 55). Tentava-se superar os limites herdados do enfoque restrito à formação profissional para o desenvolvimento econômico, à teoria do capital humano, ao tecnicismo e às teorias reprodutivistas (Franco, 1990). O tema subjacente às discussões sobre a profissionalização, a preparação para o trabalho e a educação do trabalhador, era o trabalho como princípio educativo e a politecnia.
Nos anos de 1990, Shiroma e Campos (1997), fazendo um balanço das pesquisas em educação sobre qualificação e reestruturação produtiva, registraram a presença de profissionais de áreas afins nos eventos de educação: da sociologia do trabalho, da engenharia de produção e da administração. Os estudos vão receber influência dessas áreas quanto ao quadro de referências conceituais, às abordagens, à apropriação de conceitos e ao delineamento das pesquisas (Shiroma \& Campos, 1997, p. 21).

Do ponto de vista teórico-metodológico, no presente artigo, valemo-nos de estudos similares denominados "estados da arte" ou "estados do conhecimento". Azevedo e Aguiar (2001) fizeram um estudo da produção do conhecimento sobre política educacional no Brasil com base na produção apresentada no GT Estado e Política Educacional, no período 1993-2000. Com base em Bourdieu, trazem, como questões preliminares, os processos de reconhecimento e legitimidade conferidos àqueles que participam de um determinado campo científico. Para essas autoras, a estrutura que se cria em um campo depende do tipo de luta científico-política pela legitimidade do saber, o que também é influenciado por fatores externos ao campo. "Neste contexto, em todos os campos são encontrados os dominantes, cujas posições advêm do reconhecimento do montante do capital científico de que são detentores, e os dominados, ou novatos, que necessitam ter reconhecida a importância de seu capital, de suas potencialidades, bem como de sua posição atual e potencial no campo. Entretanto, é o resultado do jogo de forças nele presentes que vai permitir, ou não, o avanço significativo da produção do conhecimento de que o campo se ocupa" (Bourdieu apud Azevedo \& Aguiar, 2001, p. 50).

No caso do GT Trabalho e Educação, o reconhecimento do campo se fez com clara explicitação da busca de afirmação política dos setores progressistas da sociedade civil em processo de democratização nos anos de 1980 e de crítica às políticas neoliberais nos anos de 1990. O movimento de legitimação do materialismo histórico como referencial analítico 
fundamental do campo se fez, particularmente, pelas lideranças incisivas e permanentes de Miguel Arroyo e Gaudêncio Frigotto, desde a criação do GT até meados dos anos de 1990. Complementarmente, atuaram Acácia Kuenzer, na vinculação do campo com o ensino médio e na "pedagogia da fábrica"; Lucília Machado, na discussão do ensino técnico e da politecnia; Paolo Nosella, nos estudos gramscianos; Maria Ciavatta Franco, nos estudos históricos com documentação de época; Ozir Tesser, no referencial lukacsiano; Celso Ferretti, nos estudos sobre tecnologia e reestruturação produtiva.

Em um segundo momento, emerge de modo significativo o questionamento às análises marxianas, através de Werner Markert e seus estudos sobre profissionalização e competências, tendo por base o referencial da Escola de Frankfurt. Nesse momento também se fazem presentes, com Paulo Tumolo, os estudos sobre sindicalismo, além de alguns trabalhos polêmicos com base em autores ditos pós-modernos.

Com o crescimento da afluência às reuniões anuais da ANPEd, no início dos anos de 1990, cria-se o Comitê Científico para a avaliação crítica dos trabalhos (o que, antes, era feito pelos coordenadores dos GT). Introduzem-se as mesas-redondas e os trabalhos encomendados. No GT Trabalho e Educação abrem-se novos espaços de participação, com uma seleção de temas a cargo dos participantes mais expressivos do GT e de convidados, ao lado da apresentação de trabalhos, comunicações ou posters por novos participantes vindos dos mestrados e doutorados em expansão no país.

Do ponto de vista do "estado do conhecimento" que nos propomos a fazer, cabem alguns comentários. Ferreira (2002) analisa esse tipo de estudos e seus desafios, ao mapear uma certa produção acadêmica em diferentes campos do conhecimento, tempo e lugar, com base em diversas formas de apresentação (teses, dissertações, artigos em periódicos, comunicações em congressos e seminários). Os catálogos (impressos ou em CD-ROM) vão permitir a socialização de uma produção científica crescente nas universidades; além de proporcionarem os primeiros contatos entre pesquisadores, o rastreamento do que já foi estudado, caracterizando seu conteúdo e divulgarem os dados bibliográficos dos autores. Os resumos são elaborados para elucidar o objetivo principal da investigação, a metodologia, os procedimentos utilizados, os sujeitos da pesquisa, os resultados e as conclusões.

A pergunta básica da autora é se é possível interrogar a história da produção acadêmica com base apenas na leitura de dados bibliográficos e resumos dos trabalhos. É possível inventariar a produção, suas tendências e suas escolhas metodológicas e teóricas por um processo de aproximação ou de distanciamento entre os trabalhos expressos nos resumos, sem ter o contato com o todo? Há sempre o risco de se classificar ou agrupar erroneamente os trabalhos. ${ }^{1}$

Várias questões se colocam: os resumos não são homogêneos na sua estrutura e na ênfase aos diferentes aspectos resumidos, de uma mesma obra pode ter sido feito mais de um resumo, com ênfases diversas, apresentando diferentes pistas ou indícios da pesquisa; a história da produção acadêmica analisada será sempre "umas das possíveis histórias" (idem, p. 269, grifo da autora). Há um certo relativismo, não claramente explicitado no trabalho, trazido pela polifonia dos resumos e das leituras possíveis dos mesmos, que seria "resolvido" através da noção de rede.

Mas é válido o alerta sobre os riscos de tomar a parte pelo todo, ao analisar apenas os resumos com o objetivo de construir a história da produção acadêmica de determinado grupo, em certo período. Embora, conforme a autora, "é possível ler em cada resumo e no conjunto deles outros enunciados, outros resumos, outras vozes, e perceber a presença de certos aspectos significativos do debate sobre determinada área do conhecimento", desde que não se reduza a pesqui-

\footnotetext{
${ }^{1}$ A autora, em sua tese de doutorado sobre o tema, trabalha
} com a noção de gênero do discurso de Mikhail Bakhtin (1997) e com a noção de suporte material com base em Chartier (1996) e, finalmente, a noção de rede, questões que não discutiremos neste trabalho (Ferreira, 2002, p. 267-270). 
sa ao resumo e não se veja entre os resumos uma relação de contigüidade, já que em cada resumo haveria uma relação de continuidade e de ruptura com o trabalho que lhe dá origem (Ferreira, 2002, p. 270).

Por outro lado, assumimos neste artigo que a história é a produção da existência humana. Ao produzi-la, tanto considerando a história como processo quanto considerando-a como método, colocamos nossos valores e ideologias. Assim, a história construída é sempre fruto de opções conceituais e metodológicas, imbuídas de uma determinada visão de mundo, certo referencial analítico, que conduzem à afirmação de uma verdade aproximada. O que lhe retira um possível relativismo subjetivista, na medida em que está subjacente à história escrita a produção material e seus aspectos sociais e culturais.

$\mathrm{O}$ trabalho que realizamos, no primeiro momento, teve por base os seguintes aspectos: a) recuperar os trabalhos sobre o histórico do GT e sobre o "estado do conhecimento" do tema Trabalho e Educação disponíveis: Kuenzer (1987), Trein e Picanço (1995), Trein (1996 a e b), Shiroma e Campos (1997), Trein (1998) e Kuenzer (1998), ${ }^{2}$ b) proceder à leitura dos resumos dos trabalhos apresentados e discutidos no GT de 1996 a 2001; c) fazer o levantamento das questões conceituais, teórico-metodológicas e empíricas dos trabalhos apresentados; d) e, finalmente, proceder à leitura e à análise de vários textos completos que desenvolveram as temáticas mais recorrentes em cada reunião anual do GT.

Entendemos que, por ser uma área de estudos ligada às relações capital e trabalho, as transformações socioeconômicas e políticas precisam ser reconhecidas e estudadas. Trata-se de compreender o campo empírico no qual as pesquisas se realizam, as categorias e conceitos privilegiados pelos diversos autores em seus trabalhos e o sentido político das análises desenvolvidas.

${ }^{2}$ Complementarmente, registramos as indicações metodológicas dos seguintes trabalhos: Franco e Baeta (1985) e Wittmann e Gracindo (2001).

\section{Breve histórico do GT Trabalho e Educação}

Desde sua criação, a ANPEd superou a proposta dos órgãos do Estado - ser uma associação de programas de pós-graduação - e definiu-se abrangendo esses programas como sócios institucionais, ao lado de sócios individuais, professores, pesquisadores e também pós-graduandos. Constituiu-se assim, em um espaço vivo e dinâmico de debates e de socialização das pesquisas do campo educacional brasileiro, em permanente interlocução com a produção internacional da área.

Nesse contexto, durante a $4^{\mathrm{a}}$ Reunião Anual, realizada em 1981, foram criados os grupos de trabalho da ANPEd, entre os quais o GT Trabalho e Educação. Eram apontados como objetivos dos grupos: promover a discussão sobre como os trabalhos apresentados poderiam contribuir na pós-graduação, na graduação, no ensino fundamental e médio e na construção crítica da prática pedagógica; promover o intercâmbio entre os grupos de pesquisa da área; organizar publicações da ANPEd que facilitassem a circulação dos resultados de pesquisa e a apresentação de temáticas consideradas novas ou insuficientemente pesquisadas.

O GT Trabalho e Educação desenvolveu-se com características muito próprias. Num debate ocorrido durante a $9^{\mathrm{a}}$ Reunião Anual, Miguel Arroyo assim se expressou sobre a orientação assumida pelo GT: “Tentamos dar-lhes uma conotação de debate, de verdadeiro intercâmbio, e não só de apresentação. Debatemos principalmente as demandas que estão surgindo, para as quais precisamos de respostas novas, para o que ainda não há muitos espaços" (Trein \& Picanço, 1995, p. 87).

Desde a sua criação, o GT Trabalho e Educação vem se pautando por duas preocupações centrais: entender o mundo do trabalho como processo educativo, vale dizer, compreender a pedagogia que se desenvolve nas relações sociais e produtivas no modo de produção capitalista e identificar os espaços de contradição que engendram a construção de uma nova pedagogia comprometida com os interesses da clas- 
se trabalhadora. Essa opção implicou a explicitação de um referencial teórico-metodológico que vem constituindo sua identidade. Assim, o GT vem se construindo menos como um recorte no campo educacional e mais como a busca da elaboração conceitual que auxilie na compreensão da formação humana.

Inicialmente o GT denominou-se Educação e Trabalho, mas a concepção de trabalho enquanto práxis humana, material e não-material, que constitui o trabalho como princípio educativo - e que portanto não se encerra na produção de mercadorias -, exige que a educação seja compreendida em suas múltiplas determinações, conforme o estágio do desenvolvimento das forças produtivas e das relações de produção. Dentro de uma visão dialética da história, no quadro dos estudos e publicações sobre Marx e Gramsci, formou-se a idéia de que não se pode compreender a escola dissociada da sociedade a que ela pertence. Nesse sentido, a escola e a educação não devem ser estudadas como unidades autônomas, mas dentro das relações sociais de que fazem parte. Essas reflexões determinaram a mudança do nome do GT para Trabalho e Educação (Kuenzer, 1987).

Ao longo do tempo, o GT passou por diversas coordenações. A primeira foi de Jacques Velloso (1981-1982), seguido de Miguel Arroyo e Gaudêncio Frigotto (1982-1988). Em 1987, na $10^{\text {a }}$ Reunião Anual, implantou-se a experiência da coordenação colegiada, incluindo-se Nilton Fisher. $\mathrm{Na} 11^{a}$ Reunião Anual, a coordenação foi assumida por Gaudêncio Frigotto, Paulo Nosella e Iracy Picanço (1988-2000). Algumas dificuldades operacionais fizeram com que as coordenações seguintes fossem assumidas por apenas uma pessoa com a colaboração informal de outros colegas. Assim sucederam-se na coordenação Iracy Picanço (1991-1993), Eunice Trein (1994-1996), Celso Ferretti (1997-1998), Lucília Machado (19992000) e Paulo Tumolo (2001-2002).

O GT vem realizando encontros periódicos entre as reuniões anuais da ANPEd, para viabilizar o intercâmbio entre grupos de pesquisadores da área. Esses encontros envolvem a coordenação do GT e programas de pós-graduação que dão suporte aos eventos. Neles tem sido possível realizar balanços periódicos da área trabalho e educação e discutir as pesquisas em andamento, seus avanços e dificuldades, bem como traçar agendas de novas temáticas que emergem na sociedade brasileira e que desafiam a área. Resultaram desses encontros algumas publicações, dentre elas: Trabalho e conhecimento (Gomez et al., 1987), Trabalho, educação e prática social (Silva, 1991), Trabalho e educação (Kuenzer et al., 1992), Educação e crise do trabalho: perspectivas de final de século (Frigotto, 1998), Trabalho \& Educação, Revista do Núcleo de Estudos sobre Trabalho e Educação da Faculdade de Educação da Universidade Federal de Minas Gerais (NETE/FaE/UFMG) (a partir de junho/julho de 1996), Trabalho \& Crítica, Anuário do GT Trabalho e Educação (a partir de setembro de 1999).

O primeiro e mais alentado "estado do conhecimento" na área foi realizado por Acácia Kuenzer e publicado pelo Instituto Nacional de Estudos e Pesquisas Educacionais Anísio Teixeira, do Ministério da Educação (INEP/MEC), em 1987, com o título Educação e trabalho no Brasil: o estado da questão. Como foi dito, resultou do primeiro encontro de pesquisadores da área, com a finalidade de propor uma agenda de trabalho. Em 1996, após três anos como coordenadora, Eunice Trein (1996a) faz um balanço das atividades do GT em entrevista publicada no periódico Trabalho e Educação $\mathrm{n}^{\circ}$ 0, do Núcleo de Estudos Trabalho e Educação da UFMG. Esse balanço foi retomado como análise da produção da área no período de 1991 a 1996 e apresentado em sua palestra de abertura do seminário de 1996, promovido pela Faculdade de Educação da Universidade Federal do Paraná (UFPR) e coordenado por Acácia Kuenzer (Trein, 1996b). Um terceiro balanço, composto pelos informes dos núcleos de pesquisa em Trabalho e Educação que participaram do seminário promovido pelo Núcleo de Estudos em Trabalho e Educação da UFMG, em 2000, coordenado por Lucília Machado, foi publicado em Educação em Revista, da Faculdade de Educação da UFMG, n 33, de junho de 2001.

Os encontros e debates, somados às reuniões 
anuais da ANPEd, têm dado visibilidade ao grupo e garantido a participação constante de número expressivo de pesquisadores de diversas regiões do país. O GT conta com um núcleo de participantes permanentes, em torno de quarenta pessoas, e outras tantas que variam ao longo do tempo. A procura do GT para a apresentação de trabalhos também tem sido expressiva, colocando-o entre os dez mais procurados grupos de trabalho da ANPEd, no conjunto de cerca de 20 GTs que compõem a ANPEd.

\section{A produção científica do GT Trabalho e Educação (1996-2001)}

Retomando a pauta elaborada no encontro coordenado por Kuenzer em 1987, Trein (1996a), no balanço das temáticas propostas em 1986 e de seus desdobramentos ao longo de dez anos, destacou os seguintes temas:

a) Trabalho e educação - teoria e história: o trabalho como princípio educativo; a evolução histórica do conceito de trabalho; a relação trabalho e educação e sua reconstrução histórica.

b) Trabalho e educação básica: o trabalho e a continuidade/descontinuidade da escolarização do trabalhador; o mundo do trabalho, a escola e a formação científico-tecnológica do trabalhador.

c) Profissionalização e trabalho: a análise histórica das políticas de profissionalização definidas pelo Estado; trabalho, conhecimento e cidadania para a emancipação do trabalhador.

d) Educação do trabalhador nas relações sociais de produção: reestruturação produtiva, apropriação do conhecimento nos processos produtivos; a organização da produção e suas propostas pedagógicas; a escola, o trabalho, a sociedade e a construção da hegemonia.

e) Trabalho e educação nos movimentos sociais: a construção de identidades de diferentes categorias de trabalhadores; demandas de conhecimentos científico-tecnológicos dos movimentos sociais com base na produção; a ação pedagógica nas formas cooperativistas de organização dos trabalhadores.

No presente artigo, analisamos as temáticas mais recorrentes nas reuniões anuais do GT, de 1996 a 2001, classificadas de acordo com as categorias acima, tendo a preocupação de identificar quais desses temas permanecem e quais são as temáticas emergentes. Em linhas gerais, observamos dois grandes eixos temáticos - a reestruturação produtiva e a nova organização do trabalho - e suas consequiências para a formação profissional. Este último tema é desenvolvido considerando as políticas de formação do ponto de vista do Estado, de sua vinculação com os organismos internacionais (Banco Mundial - BM, Banco Interamericano de Desenvolvimento - BID, Comissão Econômica para a América Latina - CEPAL), com base na visão dos empresários ou da perspectiva do movimento sindical.

Com a mesma importância, em termos de número de trabalhos, estão os estudos sobre a relação trabalho e educação e seus pressupostos teóricometodológicos. Em menor número estão os textos sobre o trabalho e a educação básica e os referentes a trabalho, educação e os movimentos sociais. No período estudado aparecem também outras temáticas às quais poucos têm se dedicado no GT, tais como: trabalho infantil, trabalho, gênero e etnia, teleducação.

Do ponto de vista do campo empírico de pesquisa, grande número de trabalhos se ocupa da revisão analítica da literatura produzida sobre o tema e os subtemas. Mas um número considerável de trabalhos tem como campo empírico empresas, sindicatos e escolas, com base na observação, em entrevistas com gerentes e com trabalhadores e na análise de documentação.

\section{Trabalho e educação - teoria e história}

Até 1996, a análise efetuada sobre essa temática indica que o trabalho como princípio educativo era recorrente em nossas discussões, tendo como matriz principal o materialismo histórico (Marx, Lukács e 
Gramsci). Mas já incorporava os teóricos da Escola de Frankfurt, onde se enfatiza a formação do sujeito, embora ainda no âmbito do projeto da modernidade (Trein, 1996a). Continuam recorrentes no GT o conceito de trabalho, a relação trabalho e educação e sua reconstrução histórica, que permanecem como temas de interesse do grupo, mas com tratamento diferenciado. Embora o enfoque marxiano seja necessariamente do objeto compreendido na sua historicidade, são raros os trabalhos de resgate histórico da relação trabalho e educação com fontes documentais de época que não sejam do presente (Nosella \& Buffa, 1997; Franco, 1998; Moraes \& Franco, 1999). O estudo dos fenômenos é feito, via de regra, com bae em problemas atuais ou do passado recente.

Observamos um retorno aos clássicos, notadamente Marx e Lukács, realizando uma releitura crítica dos mesmos diante dos problemas postos pela globalização ou pela mundialização do capital. Tumolo (1996) faz uma análise da temática trabalho e educação propondo que se discuta o fenômeno educacional à luz do novo padrão de "acumulação flexível de capital". Da análise do "modelo japonês" emergem os questionamentos quanto à eficácia da produção diversificada, principalmente em grandes mercados, e quanto aos limites da automação e aos supostos benefícios conferidos aos trabalhadores japoneses (a ocupação vitalícia, o princípio da senioridade, os sindicatos de empresa, as negociações coletivas, os salários e as condições de trabalho e o mercado de trabalho). Em outros termos, o questionamento é se o modelo tem caráter universalizante, se pode ser transferido e se é uma superação do taylorismo/fordismo. Tumolo conclui que quaisquer que sejam os processos de trabalho, modelos ou trajetórias, é necessário "compreendê-los como processos subordinados ao processo de valorização do capital, ou seja, ao processo de produção capitalista", em um trabalho analítico que vai do "concreto aparente" ao "concreto pensado" e, assim, buscar desvendar suas múltiplas determinações e contradições (Tumolo, 1996, p. 13-15).

Santos busca ir além de sua própria análise, "que reduz a riqueza da vida na fábrica à resistência dos trabalhadores à organização capitalista do trabalho, não vendo aí senão a dimensão política em jogo no trabalho" (1996, p. 2). Considera as "diferentes formas de criatividade, de iniciativa e de autonomia na tomada de decisões por parte dos trabalhadores" e faz a análise da "experiência de trabalho", "o cotidiano do trabalhador na fábrica, como espaço de vida" (idem, ibidem). Partindo do conceito marxiano de trabalho concreto e trabalho abstrato, e segundo uma releitura de autores franceses, principalmente Ives Schwartz, discute a relação entre concepção e execução, entre trabalho prescrito e trabalho real, como espaço de saber dos trabalhadores que possibilita o desenvolvimento de um projeto tecnológico.

Analisando outro ângulo da questão temática, Leher critica a noção de tempo linear, hegemonizado pelo modo de produção capitalista e implícito nas políticas do Banco Mundial, que concebe a relação entre trabalho e educação como o "principal meio capaz de conduzir os países, regiões e pessoas a se ajustarem ao tempo hegemônico no qual a educação se confundiria com as categorias tempo, desenvolvimento e crescimento" (1996, p. 11). Defende que a área trabalho e educação ganharia maior concretividade se adotasse um conceito de tempo e de periodização que rompesse com o continuum do tempo hegemônico, que impede a visualização de rupturas e de utopias construídas pelos trabalhadores com base em sua experiência histórica.

A questão teórica é preocupação também do ponto de vista do indivíduo e de sua individualidade na sociedade capitalista. Palangana (1998) parte de pensadores clássicos e contemporâneos para analisar as condições socioistóricas nas quais emerge o indivíduo burguês, a consciência de si, a submissão e o controle da individualidade.

Por sua vez, Tumolo retoma a questão conceitual tratando "da subsunção formal do trabalho à subsunção real da vida social ao capital" (2000, p. 27). Após refletir sobre algumas categorias marxianas relativas à questão - divisão manufatureira e divisão social do trabalho, subsunção formal e subsunção real do trabalho ao capital, valor e preço da força de trabalho, o 
fordismo e o processo de trabalho e da vida do trabalhador e o atual padrão de acumulação e subsunção real da vida social ao capital -, o autor conclui que, para que os meios e instrumentos de trabalho deixem de ser elementos de degradação, aviltamento e destruição do gênero humano e se tornem instrumentos de sua emancipação, é necessária a construção de uma nova ordem societária para além do capital.

Frigotto (1998) apresenta uma reflexão sobre a questão teórica, assinalando: os desafios teóricometodológicos da relação trabalho e educação, no contexto da crise dos paradigmas das ciências sociais, e a forma como os estudiosos da área constroem suas análises sobre o papel da educação e da formação técnico-profissional na produção social da existência. Coloca em pauta a reestruturação produtiva, a globalização excludente e a crise estrutural do trabalho assalariado. Salienta que as escolhas teóricas não são aleatórias, mas se integram à luta ético-política na compreensão e na transformação do mundo social, em uma sociedade profundamente marcada pelas diferenças de classe. Admitindo que o materialismo histórico está em crise, considera que não se trata apenas de reconhecer a superação de algumas análises datadas de Marx e Engels, mas de historicizar o núcleo de suas teorias em função dos problemas do presente. Trata-se de entender as formulações teóricas conflitantes ou antagônicas e, como quer Gramsci, incorporá-las de forma subordinada (Frigotto, 1998, p. 25-26). Conclui que o grande desafio colocado para o GT é "apreender as mediações no plano econômicosocial, cultural, simbólico e educativo" (idem, p. 50) que articulam as lutas das classes trabalhadoras, as formas de organização do trabalho e os processos educativos que emergem da organização dos excluídos, a exemplo do Movimento dos Trabalhadores Sem Terra (MST) e dos processos que vêm sendo denominados como "economia popular".

No mesmo ano, Kuenzer (1998) dedica-se ao exame das relações entre trabalho e educação na constituição do GT. Recupera duas de suas preocupações iniciais: compreender a pedagogia capitalista e identificar os espaços de contradição que tornam possível a construção histórica de uma nova pedagogia, "inscrevendo-se a produção do GT no campo do materialismo histórico, que toma a dialética como lógica e teoria do conhecimento" (Kuenzer, 1998, p. 55). O que significava pôr a pesquisa a serviço dos interesses das classes trabalhadoras, buscando compreender o mundo do trabalho e os processos pedagógicos escolares e não-escolares. Examina o uso das categorias de conteúdo e metodológicas, especificamente a dimensão da práxis, a articulação das categorias micro e macroeconômicas, o método da economia política, a articulação parte e totalidade, concreto e abstrato, objeto e sujeito, histórico e lógico, conteúdo e forma, pensamento e realidade. Para a autora, não se trata de optar pelo teórico ou pelo empírico, mas de articular essas duas dimensões fundamentais da pesquisa. Destaca a dificuldade de trabalhar com as categorias do método dialético: práxis, totalidade, contradição e mediação. No que concerne à categoria trabalho e a sua suposta perda de centralidade como categoria analítica, questiona o desvio do uso de categorias que não estariam perpassadas pela lógica da mercadoria, como subjetividade, linguagem virtual e manifestações culturais. Reestruturação produtiva é outra categoria a ser tratada nas suas dimensões regionais e sociais para que se avalie a pertinência da educação profissional oferecida aos trabalhadores, fora da retomada da teoria do capital humano que alimenta as idéias da empregabilidade sem atentar para as condições de risco social e a demanda por educação básica dos trabalhadores.

A centralidade do trabalho e a centralidade da educação são discutidas por Castro (1998), que questiona as pseudoevidências do senso comum pós-moderno sobre a era pós-trabalho, centrada no conhecimento e na educação. O pensamento empresarial estaria exigindo: a mercantilização ampla e irrestrita do ensino através da atuação mais incisiva do empresariado; a consideração de que as despesas em educação e formação profissional são investimentos estratégicos para as empresas; "o lucro deve ser o critério orientador a todos os sistemas de ensino"; a educação permanente da força de trabalho, que favo- 
receria a ampliação do sistema privado e comercial de ensino (Castro, 1998, p. 1-2). São ainda previstos grandes negócios com a expansão da teleducação e a comercialização dos novos materiais pedagógicos (computadores, periféricos etc.). A centralidade da educação modernizada assenta-se no falso pressuposto da correlação direta entre educação e emprego, na ideologia da "empregabilidade". Embora as novas bases tecnológicas demandem de modo crescente trabalho intelectual "morto" e em menor proporção trabalho intelectual "vivo", não se modifica a relação fundante do capitalismo, que é a incorporação de diversas formas de trabalho produtor de mercadorias. Critica ainda a "visão neo-racionalista (Offe, Habermas, Gorz, Kurz) [em que] o trabalho assalariado teria deixado de ser o fundamento estruturante da sociedade moderna" (Castro, 1998, p. 13).

Markert pergunta se "neste novo modelo de competências podemos encontrar somente uma 'mistificação' da antiga discussão sobre as mudanças da qualificação no capitalismo, ou trata-se realmente de um conceito pedagógico universal que reflete o novo patamar dos conceitos de produção" (2000, p. 146). Busca, então, examinar as novas competências no mundo do trabalho e no mundo social; a relação entre suas categorias centrais "trabalho" e "comunicação"; e a contribuição do conceito de competências para a formação do trabalhador. Partindo do referencial habermasiano, o autor faz uma releitura de Marx, segundo o qual "o conjunto das relações sociais" é entendido "na dialética entre atividade produtiva (trabalho) e relação humana (comunicação)" (idem, p. 37). As novas competências exigidas pela nova organização do trabalho devem ser compreendidas como parte das "experiências" que "são as formas de compreender a realidade e a reação ativa às condições desta realidade [...] são momentos coletivos, mediados pelas noções e pela linguagem, com a realidade da sociedade" (idem, p. 40). Embora não sinalizada pelo autor, a questão polêmica que emerge desse tipo de análise é a primazia da comunicação nas relações capital e trabalho, em detrimento da estrutura de classes.

Em 2001, Markert volta ao tema tentando apre- sentar "uma concepção emancipatória da competência". Questiona o conceito de competências que contribua apenas para a conformação da subjetividade dos trabalhadores à ideologia do capital e desenvolve a análise das categorias trabalho, universalidade, comunicação e sensibilidade, tendo por base a relação entre materialismo histórico e teoria da ação comunicativa (Markert, 2001, p. 143). O autor busca as "categorias norteadoras de um conceito políticopedagógico de competência que pretenda não somente refletir criticamente as estruturas econômicas, mas tenciona, dialeticamente, prever as 'possibilidades objetivas' do sistema capitalista [...]” (idem, p. 14). Nesse texto, mais claramente, Markert parte de Adorno e polemiza com uma questão teórica básica do GT, que é a não inclusão da categoria classe social nas análises.

$\mathrm{Na}$ mesma linha teórica, Nogueira filia-se aos pensadores que buscam "descentrar o trabalho como determinante social" e critica Marx e o marxismo, focalizando o diálogo de Habermas com Lukács. Na busca de "uma teoria que aponte para a emancipação do homem" (Nogueira, 2001, p. 11), Habermas tem a teoria da ação comunicativa como central em sua concepção. O trabalho é concebido como um agir instrumental. Nesse sentido, Habermas opõe-se à centralidade da categoria trabalho em Marx e na ontologia do ser social de Lukács. Como Adorno, não se ocupa da contradição entre as classes sociais, tema basilar do pensamento de Marx e Lukács.

Posicionando-se dentro do pensamento marxista lukacsiano, Macário (2001) faz, primeiro, uma releitura do conceito de trabalho como categoria fundante da ontologia do ser social. Afirma, portanto, a centralidade do trabalho como determinação social da vida humana. A seguir, com base no conceito de teleologia primária e teleologia secundária, reflete sobre o fenômeno educativo (a educação) como uma práxis social informada por valores definidos pela luta entre as classes sociais. Na sociedade capitalista em que vivemos, a ideologia liberal institui esses valores no seu sentido universal, desvinculados da prática histórico-social. Contraditoriamente, defendem-se esses valores, en- 
quanto se convive com a negação de sua realização objetiva na sociedade e na educação.

O ano de 2001 caracteriza-se pela preocupação e pela polêmica em torno de questões teóricas, particularmente o marxismo e a teoria de Harbermas. Ferreira (2001) trata da crise dos referenciais e os pesquisadores em trabalho e educação. Aborda de modo abrangente o tratamento teórico em um conjunto de teses de doutorado produzidas de 1994 a 1998, situadas no campo trabalho e educação, utilizando "teorias historicistas, em especial o marxismo, assim como aquelas ditas pós-modernas" (Ferreira, 2001, p. 114). Mas, dos 34 trabalhos pesquisados, somente dez "produziram teses que não se alinham com o materialismo histórico [...] o que não significa afirmar que não reconhecem os problemas enfrentados pela teoria" (idem, p. 10).

Em trabalho encomendado pelo GT para a $23^{\mathrm{a}}$ Reunião, realizada em 2000, Frigotto faz um balanço da "nova e da velha faces da crise do capital e o labirinto dos referenciais teóricos", apontando o que seria uma espécie de “'debandada' dos intelectuais marxistas, migrando para outras posturas e concepções, e, de outro, uma certa acomodação e silêncio dos que continuam trabalhando com este referencial" (2001, p. 21-22). Alerta para a adoção de novo paradigma científico-neoliberal, pós-estruturalista ou pós-moderno e pós-crítico, numa sociedade pós-industrial ou sociedade do conhecimento e pós-política. Tendem a prevalecer as teorias conservadoras que naturalizam o capitalismo como única realidade possível. Sua crítica fundamental é que tais posturas não distinguem a permanência do modo de produção capitalista que continua vigente e as novas formas com que se apresenta. Afirma haver mudanças bruscas, sem precedentes, das relações sociais capitalistas, e que muitas de nossas categorias não dão conta de apreender a especificidade dos fenômenos em curso sob a nova sociabilidade do capital. Apresenta como questão fundamental dessa nova sociabilidade a crise do trabalho assalariado, a maximização da exploração e o fim de sua capacidade civilizatória. No plano teórico e da práxis, destaca a dimensão de totalidade concreta, as categorias trabalho, modo de produção da existência e classe social (Frigotto, 2001, p. 21-29). Com Jameson, conclui que "o referencial marxista é o único que permite uma crítica radical e sem celebrações ao capitalismo" (idem, p. 38, grifos do original). O horizonte da superação do capitalismo é "a construção de um novo projeto societário, efetivamente socialista" (idem, p. 43).

\section{Trabalho e educação básica}

No documento produzido com base no seminário ocorrido em 1986 (Kuenzer, 1987), os pesquisadores da área apontavam para a necessidade de discutir o tema "trabalho e educação básica" de acordo com duas dimensões principais: "a que assume esta relação a partir do trabalhador, no âmbito do trabalho coletivo, como um 'aluno' que já ocupa um posto de trabalho e [...] a que assume esta relação a partir da 'agência formadora', subentendendo-se aí o caráter mediador do Estado, que indicará a existência de distintas formas educativas para distintos grupos de trabalhadores, o que revestirá a educação básica de distintas concepções" (Kuenzer, 1987, p. 93). Hoje, tal como tem sido tratado, o tema ampliou-se e apresenta uma complexidade maior à medida que as investigações empíricas recaem sobre o enfoque dado pelos empresários, o enfoque sindical e, também, sobre o imbricamento entre o público e o privado.

No trabalho de Rummert (1998) são cotejados os diferentes discursos que explicitam as concepções de educação básica de qualidade formuladas pelas entidades representativas dos empresários (Confederação Nacional da Indústria - CNI -, Federação da Indústria do Rio de Janeiro - FIRJAN -, Pensamento Nacional das Bases Empresariais - PNBE) e aquela formulada pelas entidades representativas dos trabalhadores (Central Única dos Trabalhadores - CUT -, Confederação Geral dos Trabalhadores - CGT -, Força Sindical - FS). Pela análise de documentos, entrevistas e estudos da área, a autora detecta que, mais do que marcadas pelo antagonismo estrutural de classe, próprio do modo capitalista de produção, é possível 
verificar convergências e divergências nas abordagens de cada entidade, decorrentes do projeto sociopolítico e econômico com que cada uma delas se identifica. Aponta convergências entre trabalhadores e empresários, no que diz respeito a uma visão bastante negativa quanto à qualidade do ensino básico ministrado no país. Outro ponto de confluência diz respeito ao papel da educação de qualidade para que ocorram transformações no sistema produtivo brasileiro que conduzisse o país a nova onda de desenvolvimento. Rummert destaca que esse pensamento convergente nega o valor pedagógico das lutas travadas pelos trabalhadores ao longo da história, atribuindo à educação formal orientada para o mercado o poder de grande panacéia para superar as dificuldades que afetam tanto o capital quanto o trabalho. Conclui dizendo: "é necessário reconhecer que diferentes frações das classes trabalhadoras apresentam demandas e aspirações distintas [...] das expectativas de muitos dos que se dispõem a estudar e compreender sua dinâmica e característica" (Rummert, 1998, p. 15).

Outro desdobramento da temática que pudemos identificar diz respeito a um pseudoconsenso na sociedade que coloca a educação básica para os trabalhadores na ordem do dia. No texto de Cêa (1999) são desvelados os elementos contraditórios desse consenso sobre o tema, apontando que, por trás dessa investida ideológica da classe dominante, o que aparece é a ênfase numa educação básica para os trabalhadores que viabilize a construção de um país competitivo num cenário de economia globalizada. A autora sintetiza as idéias contidas nas discussões sobre a educação básica, destacando: a qualidade da educação não garante uma efetiva aprendizagem da leitura e da escrita, embora a universalização tenha sido praticamente atingida; o conhecimento, em virtude do novo padrão de desenvolvimento, é condição para a participação econômica e a melhoria da qualidade de vida; os níveis de desenvolvimento dos países na sociedade globalizada e competitiva estão atrelados aos patamares educacionais atingidos (Cêa, 1999, p. 91).

No trabalho acima, assim como em outros apresentados no GT no período estudado, desvela-se o caráter ideológico dos pressupostos que enfatizam a relevância da educação básica dos trabalhadores. São elididos os condicionantes econômicos e políticos de uma materialidade histórica que não estende ao conjunto da sociedade os avanços proporcionados pelo desenvolvimento das forças produtivas. Nesse sentido, a luta dos trabalhadores é por uma educação que contribua para a construção de uma sociedade democrática e inclusiva, o que explicita a contradição, e não o consenso, na sociedade, em relação à relevância da educação básica.

Abordagem relevante da relação trabalho e educação básica é a que diz respeito à cidadania. Em Andrade (1998) encontramos o tema tratado à luz das demandas de uma sociedade "conformada" às mudanças das transformações produtivas. Nela, a tarefa da educação é a formação de uma força de trabalho adequada aos requisitos técnico-comportamentais desse novo momento da reestruturação produtiva. Estes vão se consubstanciar no conceito de cidadãoprodutivo. Segundo Andrade, a burguesia industrial critica a questão da cultura própria da formação social brasileira como um dos entraves ao desenvolvimento do país e propõe uma educação imbuída dos valores do industrialismo e da qualidade. Essa mudança de valores possibilitaria construir um padrão brasileiro de qualidade de vida, ou seja, atenderia aos interesses da burguesia para a formação e conformação de uma força de trabalho de novo tipo, favorecendo o entendimento entre as classes e viabilizando um determinado consenso.

O tema da cidadania aparece também em estudo de caráter teórico-conceitual quando o enfoque dado é de contraposição ao ideário liberal. Em Portela (2000), através de um estudo de reconstrução histórica do conceito, são enfocadas as ações governamentais e questionadas as possíveis contribuições educacionais para a construção de uma cidadania para a emancipação humana.

Outra face da complexa relação trabalho e educação básica dos trabalhadores diz respeito à influência da teoria do capital humano, revisitada no discurso empresarial. No estudo empírico realizado por Silva 
(2002), são analisadas as ações decorrentes da lógica empresarial veiculadas nos conteúdos não manifestos no currículo escolar, mas que permeiam o espaço pedagógico. A autora discute em sua pesquisa como "o ethos empresarial reproduzido na escola possibilita aos estudantes absorverem a suposta naturalização da hierarquização e desigualdade social" (Silva, 2002, p. 190). Busca explicitar como na relação empresaescola são fomentados sentimentos de gratidão à empresa pelos benefícios usufruídos, mesmo quando os alunos não são incluídos como "capazes” ou os "mais aptos", pois a produtividade, o mérito e a capacidade de vencer são introjetadas como qualidades ou deficiências do próprio sujeito. Conclui apontando para a necessidade de rompermos com a lógica empresarial pautada na teoria do capital humano, ainda que com nova roupagem. Para a autora, é preciso pensar os sujeitos históricos como produtos e produtores de uma cultura; sujeitos capazes de organização, desconstrução e transgressão, elementos necessários para enfrentar a lógica empresarial que se apossa do imaginário dos sujeitos da educação de uma forma mecanicista e totalizante (Silva, 2002, p. 192).

\section{Profissionalização e trabalho}

A temática da profissionalização vem ganhando vulto nos estudos empíricos realizados nos últimos anos e envolve as mudanças nos processos produtivos e o novo perfil profissional exigido dos trabalhadores. Na primeira metade da década de 1990, o tema envolveu estudos sobre as escolas técnicas federais e sobre as mudanças nas políticas de formação dos cursos oferecidos pelo Serviço Nacional de Aprendizagem Industrial (SENAI) e pelo Serviço Nacional de Aprendizagem Comercial (SENAC).

Desde a segunda metade da década até os dias atuais, a questão vem ganhando novos contornos, os quais de alguma forma contemplam preocupações já presentes no "estado do conhecimento" elaborado por Kuenzer (1987). Naquele momento, a questão-chave proposta era "conhecer qual é o saber que o trabalhador precisa obter tendo em vista sua emancipação, quais são os meios e formas pelos quais ele o consegue e quanto desse saber ele obtém" (p. 94). No texto, eram destacadas duas estratégias de abordagem da questão: conhecer o pensamento das agências formadoras, e assim chegar ao trabalhador, e tentar apreender, tendo por base o próprio trabalhador inserido no processo produtivo, quais as questões de seu interesse no que diz respeito à profissionalização e ao mundo do trabalho. As abordagens apresentadas no GT, nos últimos cinco anos, têm, em sua maioria, enfatizado a primeira estratégia. A forma como isso se deu será analisada a seguir.

Alguns estudos de recorte comparativo permitem acompanhar o desenvolvimento da questão em outros países. Gentili (1996) refere-se especificamente ao caso argentino, mas sinaliza uma tendência no mundo globalizado, marcado por uma crescente retração do Estado nas políticas de formação profissional e uma influência acentuada dos parâmetros produtivistas da lógica empresarial no âmbito dos espaços formativos. Leher (1999) volta-se para as questões relativas às políticas do Banco Mundial e seus impactos na América Latina. Para ele, as conexões entre educação, segurança e pobreza constituem-se no mote para orientar políticas públicas no sentido da expansão da escolaridade básica, em detrimento da educação de terceiro grau, da ciência e da tecnologia, uma vez que o mundo subdesenvolvido deve seguir sua vocação "natural" de produtor de mercadorias de baixo valor agregado. Nos textos de Gentili (1996) e Leher (1999), a questão destacada é a surpreendente vitalidade da teoria do capital humano, em que pese as rápidas mudanças nas condições que tornaram possível o seu surgimento nos anos de 1950. Segundo os autores, a crise do capitalismo no fim do século deu novo alento à teoria, permitindo novo ajuste entre as esferas produtiva e educativa. Esse ajuste se traduz numa inversão de papéis: os empresários criam seus próprios institutos de pesquisa e as universidades são estimuladas, cada vez mais, a se adequarem às demandas imediatas do mercado.

No âmbito das políticas educacionais voltadas à formação profissional ante a globalização e às novas 
formas de organização do trabalho, Franco, em 1997, apresentou um estudo comparativo de três países México, Brasil e Itália -, com base em uma pesquisa com sindicatos. Utilizando o método histórico, contextualiza a formação profissional diante do processo de globalização que segue temporalidades diferentes nos três países. Os principais aspectos abordados foram: a ressignificação da formação dos trabalhadores; a formação profissional como moeda de negociação no México; a formação para a atenuação do desemprego na Itália, em um contexto de ampla e sólida educação básica (fundamental e média) para os trabalhadores; e as disparidades que se expressam no Brasil pela carência de educação básica e pelo analfabetismo, perante a modernização tecnológica e organizacional do toyotismo. Das análises emerge o tema da participação concebida como o "binômio empresa-trabalhador", manifesto na ideologia dos interesses comuns entre a empresa e os trabalhadores no novo modelo produtivo (Franco, 1998b, p. 127).

Por sua vez, Hopstein (1999), ao analisar a realidade argentina e a reforma do Estado proposta pelos organismos internacionais, conclui que o verdadeiro papel que ocupa a capacitação profissional do setor público é a de obter o consenso e o compromisso dos servidores públicos na implementação das políticas de reforma estrutural do Estado. E no trabalho de Fidalgo (1999) são analisadas as experiências da França e do Brasil no que diz respeito às tendências de profissionalização dos trabalhadores e como estas vêm sendo negociadas de forma tripartite. $\mathrm{O}$ autor analisa os elementos constitutivos da nova profissionalização - a construção do consenso, a empregabilidade e a produção de competências - e conclui apontando as diferenças entre os dois países, em decorrência, segundo ele, da inserção diferenciada de cada país no capitalismo mundializado. No entanto, alerta para o fato que aproxima as duas realidades, ou seja, os objetivos dos projetos sociais são redefinidos sempre que a materialidade histórica o exija, sem escamotear o fato de que o paritarismo se dá sob o poder hegemônico do capital.

Também Rodrigues (1998), discutindo a perspec- tiva teleológica do empresariado brasileiro em diferentes momentos da história, nos alerta para essas mesmas questões. Nas últimas seis décadas, detecta como telos fundamentais: nação industrializada, país desenvolvido e economia competitiva. A cada um desses momentos corresponde uma perspectiva de profissionalização da classe trabalhadora. No entanto, como destaca, o horizonte da formação proposta pelo empresariado é o mercado, enquanto a educação que serve aos interesses dos trabalhadores é a formação humana ommilateral.

Outra abordagem da relação profissionalização e trabalho é trazida por Ramos (1996), reforçando questões também abordadas por Gentili (1996) e, mais tarde, por Rodrigues: as políticas públicas para a profissionalização objetivam "a redução significativa de seus custos e implementação de programas de capacitação de massa em detrimento da formação profissional plena e integrada ao nível médio" (1998, p. 149).

A pesquisa de Soares (1999) também corrobora essas observações, enfatizando que principalmente o ensino de jovens e adultos não tem lugar próprio no cenário educacional brasileiro. O que se observa, segundo a autora, é um mercado de trabalho excludente no qual o discurso da empregabilidade, mesmo para aqueles com elevado "capital humano", já demonstrou ser falacioso.

Santos (2002) vai discutir o novo ensino médio à luz da relação trabalho e educação enfatizando que a pretensa liberdade e flexibilidade curricular apontaria para uma educação mais adequada a cada camada social. Para a autora, como os mecanismos avaliativos denunciam, entre eles o Exame Nacional do Ensino Médio, há aí uma evidente exclusão social e de classe.

Por outro lado, Tomas e Laudares (2002), analisando os Centros Federais de Educação Tecnológica (CEFET), indicam que as mudanças advindas das novas exigências do mercado são redefinidoras do perfil profissional dos trabalhadores de nível médio. Esse trabalhador já não estaria atendendo às necessidades das grandes empresas, que passam a requisitar tecnólogos de nível superior. Todas essas mudanças 
implicam na definição de novas competências e de uma nova mentalidade de técnicos e tecnólogos que se adeqüem às exigências atuais da produção industrial. Em decorrência disso, as políticas que direcionam a reforma do ensino médio tendem a mudar de forma acelerada o perfil das escolas técnicas. A pergunta que fica é: em que medida essas novas exigências se coadunam não apenas com os interesses do capital mas também do trabalho?

Na contramão dessa tendência, que se materializa nas propostas do governo federal e dos empresários, é estudada a experiência da Escola Politécnica Joaquim Venâncio, da Fundação Oswaldo Cruz (FIOCRUZ), no Rio de Janeiro. Na análise desse caso concreto, em 1998, Amâncio Filho questiona a possibilidade de implantação de uma proposta de profissionalização no marco teórico da educação politécnica e da formação humana omnilateral, examinando os entraves, as possibilidades e as contradições do processo. A proposta de trabalho da escola em questão é voltada para uma política inclusiva de alunos das classes populares, na qual o compromisso político-pedagógico é com uma educação de qualidade, socialmente referenciada. Ao longo do período estudado, constata-se o progressivo aumento do número de alunos de classe média e a dificuldade de ter um corpo docente coeso, embora composto por profissionais de formação geral e da formação específica na área da saúde. Outra dificuldade encontrada é a alta rotatividade de professores, pois a FIOCRUZ não dispõe de corpo docente próprio, em número suficiente, para o ensino médio. Todos esses impasses sinalizam para os limites de uma experiência que ocorre no âmbito de uma materialidade histórica na qual, como já foi apontado em outras pesquisas, o capital, embora sinalize permanentemente para a importância da educação, submete os processos educativos e a profissionalização aos ditames do mercado. Nessa perspectiva, a educação politécnica constitui-se em uma educação que interessa à classe dirigente e que não deveria ser estendida ao conjunto da classe trabalhadora.

Nos estudos analisados, pudemos constatar o pensamento das agências formadoras e, com base nele, chegar à compreensão da educação e da profissionalização que é oferecida aos trabalhadores. No entanto, a outra estratégia apontada por Kuenzer em 1987, que é a compreensão ampliada da questão da profissionalização com base nos próprios trabalhadores inseridos no processo produtivo, é uma perspectiva que ainda carece de novos esforços de pesquisa.

\section{Educação do trabalhador nas relações sociais de produção}

Os trabalhos apresentados nessa categoria ocupam-se prioritariamente das transformações no mundo da produção e suas conseqüências para a educação do trabalhador, questões que ganham força a partir de 1990, com as políticas de reestruturação produtiva para maior competitividade econômica, no contexto da abertura do mercado brasileiro para o capital internacional. Os temas em foco no GT contemplam a apropriação do conhecimento nos processos produtivos; a organização da produção e suas propostas pedagógicas; a escola, o trabalho e a sociedade e a construção da hegemonia.

Em estudo mais abrangente do que os apresentados nas reuniões anuais da ANPEd, Shiroma e Campos fazem um balanço das pesquisas em educação sobre o tema qualificação e reestruturação produtiva, sinalizando as preocupações dos pesquisadores no período aproximado de uma década. São colocados em debate os temas: politecnia e polivalência, inovação nos sistemas de produção e demanda por qualificações, centralidade da educação básica, qualificação e competências e suas implicações para a empregabilidade. As autoras observam um aspecto que também está presente no GT Trabalho e Educação: “a redescoberta da educação nas agendas de empresários e governo" (1997, p. 22), ao que se deve acrescentar, também, dos trabalhadores em meados dos anos de 1990, através de suas principais entidades representativas. Esse fato sinaliza o que foi interpretado como projetos educacionais de formação profissional em disputa, desde meados dos anos de 1980, particularmente a partir da Constituinte de 1988, articulando a 
seus interesses de classe concepções, processos e conteúdos educativos, gestão de programas e recursos financeiros.

Deluiz (1996) documenta cronologicamente como empresários e trabalhadores organizaram comissões, estudos e debates em torno da automação, da nova organização do trabalho e das novas exigências de qualificação. E mostra que produtividade e eficiência são desafios estratégicos que incluem, na agenda empresarial, as novas competências e, na agenda dos trabalhadores, a gestão tripartite das agências de formação profissional (o Sistema $S$ ) e a vinculação entre educação geral e formação profissional.

Tumolo (1998) apresenta uma revisão bibliográfica crítica sobre o tema, com base em áreas afins com a educação: sociologia do trabalho, economia do trabalho, economia política, administração de empresas, educação e trabalho e engenharia. Conclui que "a intensificação da exploração sobre a força de trabalho significa uma tendencial redução nas possibilidades de implementação de propostas alternativas por dentro da ordem capitalista e implica, para a classe trabalhadora e para aqueles que com ela se identificam, a necessidade urgente da retomada da luta pela superação desta ordem" (Tumolo, 1998, p. 15).

O tema da educação dos trabalhadores perante as novas exigências da reestruturação produtiva em curso está presente de 1996 a 2001, embora com incidência progressiva em relação à compreensão do saber dos trabalhadores e às políticas de formação.

Empresários e trabalhadores foram entrevistados por Zibas para verificar as exigências de qualificação postas por algumas empresas industriais que teriam adotado com sucesso novas técnicas organizacionais denominadas "administração participativa” (1996, p. 1). O êxito das empresas de "produção enxuta" em garantir produtividade a menor custo também se faz presente na adesão dos trabalhadores entrevistados. Cada equipe de produção divide responsabilidades e controles entre os próprios trabalhadores. Minimizase o "histórico conflito que sempre se desenvolveu no local de trabalho entre empresários/gerentes ou chefes e trabalhadores". Debilita-se a solidariedade de classe porque "a nova solidariedade está voltada para os interesses da produção" (idem, p. 15).

Dos onze trabalhos apresentados em 1997, quatro dão continuidade à discussão de questões similares. Markert trata da reorganização da produção, do novo perfil do trabalhador para o trabalho em grupo, da requalificação e do modelo de cooperação entre departamentos. A pesquisa foi realizada na Alemanha, em empresas que iniciaram o processo de ilhas de produção, com a implantação do modelo acompanhada da oferta de qualificação aos trabalhadores. Observou-se que "o conceito de qualificação necessário para desenvolver essas novas capacidades nos operários orienta-se pelo processo de fluxo do trabalho, no qual os mesmos devem atuar conscientemente, e não somente executar tarefas como na fábrica taylorista" (Markert, 1997, p. 5-6). Em relação à adaptação dos trabalhadores às novas competências, aqueles de formação mais tradicional e os operários semiqualificados enfrentaram dificuldades. Quanto às empresas, o problema central encontrado foi a necessidade de mudança da hierarquia tradicional para responsabilidades descentralizadas.

Araújo (1997) estudou uma empresa que introduziu novas tecnologias organizacionais associadas ao paradigma da produção flexível integrada. Entrevistou trabalhadores, supervisores e gerentes da filial de uma multinacional, examinando as técnicas de organização do trabalho (CCQ, células de fabricação, kanbam, just in time etc.) pelas quais são valorizadas as chamadas "características pessoais", em detrimento dos saberes profissionais. Tomando como modelo analítico de formação profissional através da aprendizagem dirigida aos projetos e voltada para a transferência de conhecimento, o autor identificou as seguintes "qualidades pessoais": espírito de equipe, envolvimento e disposição para "vestir a camisa", responsabilidade, capacidade de comunicação, flexibilidade ou reatualização dos valores na ótica empresarial. Concluiu mostrando a ambigüidade do termo “qualidades pessoais", já que elas são definidas pelo sujeito principal da relação que estrutura a realidade: o capital. 
Martins (1997) estuda o processo de qualidade total na Cervejaria Brahma, a qual passa por uma modernização técnico-gerencial e institui um campo pedagógico na empresa através do sistema learning organization. $\mathrm{O}$ autor trabalhou "com o conceito de campo pedagógico na empresa para demonstrar que a instrumentalização de recursos pedagogizantes extrapola o espaço do treinamento para assumir a forma de um verdadeiro movimento social onde todos devem estar imiscuídos no processo de aprendizagem" (Martins, 1997, p. 126).

Com base nas novas exigências de escolarização dos trabalhadores, introduzidas pelas empresas, Souza (1997) examina uma empresa localizada na Bahia que implanta o Programa de Complementação de Escolaridade do Trabalhador (alfabetização, educação básica I e II, supletivo de $1^{\circ}$ e de $2^{\circ}$ graus), em parceria com a Secretaria de Educação do Estado da Bahia. Foram coletados dados com o gerente de recursos humanos e os coordenadores do programa. Quanto aos resultados obtidos, o autor observa que o programa satisfaz a expectativa dos dirigentes da empresa quanto à garantia de mão-de-obra adequada à modernização tecnológica em andamento. No que diz respeito aos trabalhadores, ele vem permitindo nova oportunidade de conhecimento e projetos pessoais de continuidade nos estudos e de ascensão funcional na empresa. No entanto, sobrepõe-se uma dificuldade fundamental: o alto índice de retenção dos alunos, no mínimo 50\% em relação ao nível inicial, chegando a $80 \%$ no $1^{\circ}$ e $2^{\circ}$ graus. As condições de estudo não favorecem o bom desempenho já que, além das condições pessoais, de turno etc., os operários têm apenas duas horas de aula por semana, o que foi considerado "um dos obstáculos ao êxito do programa" (Souza, 1997, p. 10).

Trabalho instigante foi apresentado por Bianchetti, buscando aproximar a compreensão das novas tecnologias e a apropriação do saber tácito dos trabalhadores. Com base em uma pesquisa no Centro de Gerência Integrada de Redes da empresa Telecomunicações de Santa Catarina (TELESC), o autor observa que "com os recursos propiciados pelas novas TIC - Tecnolo- gias de Informação e Comunicação e com a progressiva objetivação dos conhecimentos dos trabalhadores nos equipamentos, inseriu-se uma metamorfose ainda pouco estudada e compreendida no tocante a esse espaço-tempo de saber que dava poder aos trabalhadores" (1998, p. 14-15). Isso ocorre porque ficam disponíveis nos softwares para avaliação das gerências uma série de "registros sobre quem faz, o que faz ou deixa de fazer, quando, em que tempo e como é feito". Há uma "visibilidade das competências" ou um processo de "devassamento" de saberes, cujas conseqüências ainda demandam esclarecimentos (idem, ibidem).

Francisca Andrade (1998) estudou estratégias de formação de recursos humanos de empresas automobilísticas alemãs implantadas no Brasil (subsidiárias da Mercedes-Benz e da Daimler-Benz), visando compreender seus efeitos sobre a qualificação dos trabalhadores. Um dos resultados principais da pesquisa revelou-se no investimento das empresas no treinamento e/ou na capacitação profissional dos trabalhadores e, muitas vezes, de seus familiares e da comunidade da região onde se situa a fábrica. Reconhecendo que o trabalhador brasileiro necessita, em geral, de formação básica e profissional, as empresas buscavam qualificar os trabalhadores para a introdução da "produção enxuta". Cumpriam, também, acordos coletivos que previam que a empresa capacitaria os trabalhadores sempre que fosse introduzida uma nova tecnologia.

Buscando particularizar as relações entre a empresa e os trabalhadores no novo contexto da produção, Corrêa e Teixeira analisaram os "processos de conformação da subjetividade política" de trabalhadores de uma empresa automobilística multinacional instalada em Minas Gerais, através da educação profissional e de procedimentos participativos no interior dessa empresa. $\mathrm{O}$ aspecto inovador do sistema consiste na combinação de novas tecnologias e da "internalização das formas de controle características das relações de poder capital-trabalho [...], de uma forma aparentemente menos coercitiva, mais persuasiva e sedutora" (Corrêa \& Teixeira, 2000, p. 15). O estudo aponta ainda que "esse modelo de gestão se 
fundamenta, essencialmente, na lógica financeira com expectativas de retorno a curto prazo" para os trabalhadores, combinada a um "ambiente onde predominam o medo e a insegurança de perder seus empregos". Existem pontos de resistência que podem vir a ser estruturados (idem, ibidem).

Invernizzi (2000) realizou um amplo trabalho de análise de pesquisas realizadas durante as décadas de 1980 e 1990 em seis indústrias de ramos diversos (automobilístico, de eletrodomésticos de linha branca, complexo químico-petroquímico, de equipamentos de telecomunicações, têxtil e de calçados). Tendo por base a dinâmica da reestruturação produtiva, examinou quatro aspectos que influenciam a qualificação do trabalho: modernização tecnológica; novos métodos organizacionais; novos enfoques de gestão de recursos humanos e relações industriais; e movimento de subcontratação. $\mathrm{O}$ autor constatou dois tipos principais de impactos sobre os trabalhadores: "nova forma de utilização da força de trabalho que se baseia fundamentalmente na polivalência, na elevação do nível de escolaridade e no aumento das horas de treinamento formal por trabalhador"; e "novas formas de utilização da força de trabalho que relacionam-se com um processo mais geral de redefinição das formas de controle e disciplinamento, adequadas às novas condições da acumulação" (Invernizzi, 2000, p. 15).

Alguns autores buscam conhecer o contraponto desses processos junto aos trabalhadores ou através de suas entidades representativas. Tumolo (1997) discutiu a formação sindical na CUT, com base no novo padrão de acumulação, e o impacto das mudanças no mundo do trabalho e no sindicalismo. Apoiado em autores como David Harvey, Helena Hirata e Jorge Mattoso, observa a intensificação da exploração sobre a força de trabalho, através dos novos processos de trabalho expressos no "modelo japonês". Quanto aos impactos desses processos no sindicalismo, aponta a diminuição nas taxas de sindicalização; a separação entre trabalhadores "estáveis" e aqueles sujeitos a vínculos precários; a organização sindical dos assalariados médios; a intensificação da tendência neocorporativa que procura preservar os interesses dos trabalhadores estáveis; e a fragmentação dos trabalhadores, fragilizando a consciência de classe e dificultando ações de mobilização (Tumolo, 1997, p. 7). A CUT estaria incorporando o novo padrão de sindicalismo, a "tendência da passagem de um sindicalismo de confrontação para um sindicalismo de negociação, de concertação" (idem, p. 10). No plano da formação, a CUT estaria evoluindo no sentido de uma formação mais instrumental?

Os pesquisadores participantes do GT buscam conhecer, também, o que pensam os trabalhadores através de suas principais entidades representativas (Central Única dos Trabalhadores, Força Sindical e Confederação Geral dos Trabalhadores), sobre o papel da educação perante as transformações no mundo do trabalho. Souza, Santana e Deluiz (1999) examinaram a reestruturação produtiva e a ação sindical em relação aos seguintes aspectos: educação e mercado de trabalho, educação e cidadania, educação geral e formação profissional, educação de jovens e adultos, educação sindical, formação de formadores, competências e certificação ocupacional e inserção nas políticas públicas de formação profissional. Duas questões mais gerais podem ser destacadas: quanto à reestruturação produtiva, a CUT preocupa-se mais com a análise da lógica do sistema e "procura combater a visão de uma adequação dos trabalhadores às novas exigências", enquanto a FS e a CGT centram-se na perspectiva individual e "indicam a necessidade de o trabalhador se potencializar para a ocupação de espaços no novo modelo" (Souza, Santana \& Deluiz, 1999, p. 2).

Em uma subcategoria mais geral situam-se o estudo de Gentili apresentado em 1997 e o ensaio de Arrais Neto, em 1999. Gentili examina o desenvolvimento capitalista ante a crise global e a desintegração da escolaridade, com o fim da "promessa integradora" através da educação, do pleno emprego e da empregabilidade. Um primeiro aspecto desse processo é "o desmoronamento das expectativas no crescimento sem limite e da possibilidade teórica e empírica de distribuir democraticamente os frutos desse crescimento" que marcaram o keynesianismo. A "promes- 
sa da escola como entidade integradora" tomou forma na crença difundida da democratização dos sistemas educacionais "como poderoso dispositivo institucional de integração social”. Sua desintegração cederá lugar a uma nova promessa "de caráter estritamente privado: a promess a da empregabilidade", que veio no bojo da natureza estruturalmente excludente do fim da era dos empregos e da competência individual para a inserção no mercado de trabalho (Gentili, 1998, p. 77-78 e 89, grifo no original).

Por sua vez, Arrais Neto discute o que considera equívocos de interpretação do papel da educação ante a nova divisão internacional do trabalho. Em primeiro lugar, põe em questão a centralidade da "qualificação profissional da mão-de-obra de um país no que diz respeito à sua inserção internacional nos novos nichos da produção globalizada" (Arrais Neto, 1999, p. 30). A seguir, questiona a visão da "suposta inexorabilidade e irreversibilidade" da globalização e a "crença na possibilidade de inserção privilegiada no novo quadro da divisão internacional do trabalho" (idem, ibidem), supostamente baseada em critérios meritocráticos. O terceiro ponto posto em discussão é "a afirmação do papel da educação como catapulta fundamental para a inserção privilegiada no rol dos países ganhadores desta 'corrida' mundial" (idem, ibidem). Essa compreensão do papel da educação se apoiaria no retorno da teoria do capital humano e na ilusão da conquista da empregabilidade pela formação, como recurso ao desemprego.

\section{Trabalho e educação nos movimentos sociais}

Nessa temática, busca-se conhecer as dimensões educativas presentes nos movimentos dos trabalhadores, de forma a sistematizar suas exigências educacionais e seu pleno desenvolvimento. Para isso é preciso investigar a inserção dos trabalhadores no processo de produção, organização e gestão das condições pedagógicas específicas dos movimentos sociais.

Osowski e Martini (1996), pesquisando sobre os trabalhadores infanto-juvenis que freqüentam escolas de primeiro grau, vão discutir as representações sociais sobre o trabalho infantil, as várias apreensões que a sociedade tem do fenômeno, como as crianças vivenciam esse aprendizado e as possíveis relações que a escola estabelece entre o currículo oficial e esse "currículo oculto", presente na cultura dos jovens trabalhadores e seu familiares. Para as autoras, foi possível constatar como "um peculiar mundo do trabalho infanto-juvenil, com fortes laços com o trabalho doméstico, constitui-se num território de construção de subjetividades" (p. 8). Reconhecem que é preciso questionar a materialidade histórica que engendra essas subjetividades de forma que a escola contribua para assegurar condições de que as crianças e adolescentes possam tornar-se cidadãos comprometidos com a construção de uma sociedade mais justa.

O tema da subjetividade é abordado também por Resende (1999). Como o trabalho anterior, a construção da subjetividade é compreendida com base no mundo do trabalho, vale dizer, das condições materiais da produção da existência. Em seu estudo, a autora vai ressaltar a fertilidade da categoria trabalho, tal qual se constrói na teoria marxista, em contraposição ao reducionismo psicologizante que entende a subjetividade nos estreitos contornos da cognição e da inteligência. Em suas reflexões, percorre as grandes idéias que nortearam os séculos XIX e XX, buscando tematizar a sociedade burguesa e a idéia de homem como cidadão, "indivíduo como ser singular que aparece sintetizado na liberdade de quem pode circular lado a lado com(o) a mercadoria" (Resende, 1999, p. 160). Expõe como esse sujeito é ilusoriamente livre e autônomo e enfatiza a necessidade da compreensão desse complexo mundo burguês recolocando a subjetividade na história. Assim, para a autora, a educação não deve contentar-se com o recorte psicológico de que subjetividade é cognição, inteligência. Deve ir além, e para isso a apropriação fértil da categoria trabalho parece o caminho indicado.

Também Corrêa (2000) discute a formação da consciência política em tempos de globalização e neoliberalismo. Em estudo sobre o senso comum dos professores, sob a influência do neoliberalismo, destaca o papel mediador das instituições educacionais 
na formação do senso crítico, ou acrítico, desses profissionais. $\mathrm{Na}$ pesquisa realizada com grupos de professores, buscando identificar suas diferentes perspectivas sobre a realidade, a autora identifica a importância dos espaços de discussão coletiva para o desenvolvimento de um olhar mais crítico e político sobre suas vidas e seu trabalho. Nas discussões, foram detectadas inseguranças, preocupações e insatisfações em relação ao trabalho na escola e à própria vida desde que o pensamento neoliberal se tornou hegemônico na sociedade. Com a pressão que se intensificou na última década, a reação das professoras não tem sido a de apostar em saídas coletivas e organizadas em torno do sindicato, mas a busca de saídas individuais. No entanto, ao lado do desânimo em relação às formas tradicionais de luta, elas vislumbram no trabalho cotidiano com os alunos uma possibilidade de militância política, ou seja, através da conscientização de seus alunos poderem contribuir para a transformação da sociedade. Corrêa conclui considerando a necessidade da desconstrução da hegemonia do neoliberalismo e para isso aposta na ampliação dos espaços públicos, na afirmação da educação como um direito social e no estímulo à participação nos movimentos políticos e sociais.

Outro tema referente à questão do trabalho e da educação nos movimentos sociais, a educação do "cidadão trabalhador" pelo programa Telecurso 2000, foi abordada por Andrade (1999). Ao analisar esse programa, o autor destaca que, para além dos objetivos educacionais imediatos, pretende-se também “contribuir para o estabelecimento de um 'clima' propício à construção de um novo padrão de participação político-social dos indivíduos que compõem a população brasileira" (Andrade, 1999, p. 156). Em suas conclusões, constata que, após minucioso exame do programa, é visível, nas iniciativas elaboradas pelos órgãos representativos do empresariado, a intenção de suscitar o surgimento, nas classes trabalhadoras, "de uma camada de sujeitos individuais que possa vir a contribuir de forma consciente e ativa para apressar a incorporação [...] daqueles conteúdos conformadores do anteriormente mencionado 'novo indus- trialismo' e, portanto, daquele modo de vida a ele correspondente" (idem, p. 159).

Uma questão emergente, posta pelos pesquisadores militantes dos movimentos sociais, é a afirmação dos movimentos como princípio educativo. Essa questão tensiona o GT, que tem o trabalho, na sua dimensão ontológica e fundamental de produção da vida e da cultura, como princípio educativo.

\section{Conclusões}

Do percurso empírico e teórico-metodológico do presente trabalho, destacamos algumas questões mais gerais.

1. O GT Trabalho e Educação mantém no seu horizonte "a necessidade de desenvolver o corpo teórico da área, através de um concentrado esforço de reflexão sobre os fundamentos teórico-metodológicos da relação entre trabalho e educação, atentando para os perigos da manipulação de conceitos gerais como se fossem uma substantividade própria, independentemente de tempo e lugar" (Kuenzer, 1987). Essa base teórica no materialismo histórico traz consigo outro traço distintivo do GT: a visão política pautada pelo compromisso com a transformação das formas de exploração e amesquinhamento do ser humano, geradas pela produção e pela sociabilidade do capital. Tem prevalecido, contudo, o diálogo e o confronto com autores que questionam o marxismo ou que trazem contribuições analíticas pautadas por temas emergentes no contexto das transformações do último século, tais como a sociedade de consumo, a comunicação, a subjetividade, a presença da imagem o ideário pós-moderno.

2. Por ser uma área de estudos ligada às relações entre o capital e o trabalho, as transformações socioeconômicas e políticas precisam ser reconhecidas e estudadas. Trata-se de compreen- 
der o campo empírico no qual as pesquisas se realizam (empresas, escolas, movimentos sociais), as categorias e os conceitos privilegiados pelos diversos autores em seus trabalhos e o sentido político das análises desenvolvidas. Entendemos que os mundos do trabalho e da educação possam ser mais bem apreendidos com base nas categorias do materialismo histórico, particularmente, trabalho, totalidade, mediação e contradição.

3. O GT Trabalho e Educação, tanto nos trabalhos de caráter teórico quanto nos trabalhos mais empíricos, tem feito uma crítica radical ao ideário neoliberal, ao "fim da história" e às propostas de ajustamento ou acomodação passiva dos trabalhadores às exigências da restruturação produtiva e da nova organização do trabalho. Entretanto, não tem tematizado suficientemente as alternativas de concepção e de ação para a construção de uma nova sociedade. Quais as propostas que emergem da sociedade brasileira e que se contrapõem ao modelo vigente? Que tipo de desenvolvimento estaria contido nas propostas que vêm sendo elaboradas pelos trabalhadores, através do movimento social organizado (sindicatos, MST e administrações municipais de corte democrático popular)? Seria o caso de refletir sobre o pensamento de Celso Furtado (1998) quando defende que não há desenvolvimento econômico que não seja também desenvolvimento cultural? E que este deve ser no sentido da humanização da vida, da integração de toda a população nos benefícios da riqueza social (trabalho, habitação, saúde, educação, proteção social e previdência)?

4. De que educação básica e de que educação os trabalhadores estão falando quando reivindicam mais educação e formação profissional? $\mathrm{O}$ que sugere a necessidade de mais estudos no interior das empresas e das escolas subme- tidas, com maior ou menor adesão, às reformas do ensino médio, profissional e técnico através dos cursos modulares, do ensino à distância e da formação de tecnólogos? O ensino médio não mereceu, no período estudado, a atenção do GT correspondente à sua importância como etapa final da educação básica, necessária ao domínio de uma base de conhecimentos para a compreensão da complexa sociedade em que vivemos.

5. Os estudos historiográficos, com documentação de época, remetem à memória de um passado que ajuda a compreender o presente e a projetar o futuro. Eles são escassos no GT, seja pela urgência dos problemas do mundo do trabalho no presente, seja pela insuficiência de tempo, de recursos e de formação para o desenvolvimento da pesquisa histórica, em arquivos e/ou com outros procedimentos próprios da área.

6. Outra questão diz respeito aos canais de comunicação entre o meio acadêmico e a sociedade civil, os sindicatos particularmente. A observação sugere que, à exceção de certo número de intelectuais escolhidos pelos sindicatos, grande parte de valiosas e esclarecedoras pesquisas de mestres e doutores ficam confinadas ao meio universitário, por não haver demanda de discussão com as entidades e por falta da iniciativa de propostas da universidade. Até hoje, essa aproximação tem ocorrido em relação às empresas, onde a formação de quadros dirigentes e executores, bem como a produção de pesquisas atendendo a interesses privados, se dá de forma naturalizada, dispensando, inclusive, a aproximação direta entre universidade e empresa. Em relação aos trabalhadores a realidade é outra. Não tem ocorrido o que, em outros países, viabilizou a elevação da formação geral, não somente no que diz respeito ao nível de qualificação profissional, mas 
também de formação política, viabilizado pela existência de universidades populares e de outras formas alternativas de ensino.

7. Hoje, as universidades públicas possuem um significativo acervo de conhecimentos e um potencial de recursos pedagógicos que permitem viabilizar formas de cooperação mais estreitas entre as universidades e os trabalhadores. Isso poderia se dar em três níveis: documentação, formação e pesquisa. $\mathrm{O}$ acervo de pesquisas na área trabalho e educação existente nas universidades públicas é ainda insuficientemente socializado. E haveria uma pauta de questões que podem contribuir para que a cultura, a educação e a formação profissional, financiadas pelo fundo público, deixem de ser propriedade de poucos. A experiência de tratamento documental desse acervo pode auxiliar no trabalho de organização dos conhecimentos gerados pelos sindicatos. Poderia, ainda, auxiliar a preservação da memória do trabalho e dos trabalhadores, fonte de identidade de classe, de projetos de futuro e de resistência nas lutas do presente. $\mathrm{Na}$ área de formação, as demandas dos trabalhadores poderiam ser atendidas pelas atividades de extensão, pelos cursos de pós-graduação lato sensu, por consultoria e por encontros programados nas universidades, nos sindicatos e nas escolas de formação profissional e técnica.

8. Se isso é verdade, sugerimos a elaboração de uma pauta de atividades de extensão que viabilize a interlocução dos pesquisadores com os sindicalistas e professores das escolas profissionais e técnicas. Também seria importante resgatar o projeto preliminar da Unitrabalho que previa a disponibilização e o intercâmbio dos trabalhos de pesquisa produzidos nas universidades com os trabalhos produzidos pelos trabalhadores, através de suas entidades representativas. Mas essa não seria apenas uma atividade pontual, seletiva, e sim um projeto com linhas comuns de ação política e de permanente avaliação para a correção de rumos.

9. Quanto à formação do educador ao nível da graduação, é importante permear os estudos pedagógicos com a visão do mundo do trabalho, que tem recebido uma demanda crescente de estudos voltados para o trabalho do professor. Seria o caso de pensar a inclusão da temática trabalho e educação na grade curricular dos cursos de pedagogia e nas licenciaturas?

10. Do ponto de vista da interlocução sobre o mundo do trabalho com outras áreas do conhecimento, observamos as aproximações recorrentes com a economia, a história, a sociologia e, em menor proporção, com a ciência política e a comunicação. Sugerimos conhecer os estudos que a área de saúde tem desenvolvido sobre as condições de trabalho no mundo atual e suas conseqüências na saúde dos trabalhadores, a exemplo das pesquisas sobre a psicopatologia do trabalho (Dejours, 1992), a insalubridade (Rebouças, 1989), as "doenças dos nervos" (Duarte, 1986), a fadiga, distúrbios do sono, o estresse ou Síndrome de Burnout (Codo, 1999), a angústia e a insatisfação no ambiente de trabalho e a Síndrome loco-neurótica (Alevato, 1999). Por sua vez, um tema ausente nas discussões do GT é "a nova ética protestante" que parece estar crescendo na sociedade brasileira, já presente nas propostas de formação que emanam do setor empresarial. Essas se caracterizam pelos ethos do trabalhador disciplinado, empreendedor, ordeiro, parceiro do patrão na nova organização do trabalho. O que parece estar sendo reforçado pelas ideologias religiosas das novas igrejas de denominação "evangélica".

EUNICE TREIN, doutora em educação pela UFRJ, é professora adjunta na Universidade Federal Fluminense. Publicou: 
Trabalho e educação diante dos limites da globalização: questões teórico-metodológicas (In: Trabalho \& Educação, Belo Horizonte: NETE/UFMG, $\mathrm{n}^{\circ} 3$, p. 119-128, 1998); Conquista da Cidadania: a educação diz: presente (In: Contexto \& Educação. Ijuí: Ed. Unijuí, v. 10, n 41, p. 17-27, 1996). Projetos de desenvolvimento em disputa: reflexões sobre a questão ambiental e os limites do modelo fordista de produção (In : FRIGOTO, Gaudêncio, CIAVATTA, Maria (orgs.). A experiência do trabalho e a educação básica. Rio de Janeiro: DP\&A, 2002). Apresentou: Desemprego estrutural: desafios e perspectivas. Seminário Educação 2003 - Educação e Trabalho: trabalhar, aprender, saber (Cuiabá, MT, UFMT, 31 de agosto a 3 de setembro de 2003). Linha de pesquisa atual: Sociedade e meio ambiente: a formação do sujeito coletivo versus a formação do cidadão produtivo. E-mail: eunicetrein@ig.com.br

MARIA CIAVATTA, doutora em ciências humanas (educação), pela PUC-RJ, e com pós-doutorado em sociologia do trabalho na Università di Bologna, Itália, é professora titular na Universidade Federal Fluminense e pesquisadora associada do Programa de Pós-Graduação em Educação da mesma universidade. Coordena atualmente o GT Trabalho e Educação da ANPEd. Últimas publicações: $O$ mundo do trabalho em imagens: a fotografia como fonte histórica; Rio de Janeiro, 1900-1930 (Rio de Janeiro: DP \& A, 2002); co-organidora dos livros A experiência do trabalho e a educação básica (Rio de Janeiro: DP \& A, 2002) e Teoria e educação no labirinto do capital (Petrópolis: Vozes, 2001). E-mail: mciavatta@terra.com.br

\section{Referências bibliográficas}

ALEVATO, Hilda, (1999). Trabalho e neurose: enfrentando a tortura de um ambiente de crise. Rio de Janeiro: Quartet.

AMÂNCIO FILHO, Antenor, (1998). Limitantes para uma educação politécnica na saúde. In: ANPEd, 25 anos, CD-ROM histórico, 2002.

ANDRADE, Flávio Anício, (1999). Educação sem distância; as demandas da produção e uma proposta formativo empresarial: o programa Telecurso 2000. Trabalho \& Crítica, Anuário do GT Trabalho e Educação, ANPEd/UFF, $\mathrm{n}^{\circ}$, p. $147-159$.

, (1998). A formação do "cidadão-trabalhador": educação e cidadania no contexto do "novo industrialismo".
Trabalho apresentado na $21^{\text {a }}$ Reunião Anual da ANPEd. In : ANPEd 25 anos, CD-ROM histórico, 2002.

ANDRADE, Francisca R.B., (1998). As empresas automobilísticas e suas estratégias de formação de recursos humanos: a referência da Volskswagen e da Mercedes Benz do Brasil. Trabalho apresentado na $21^{\text {a }}$ Reunião Anual da ANPEd. In: ANPEd 25 anos, CD-ROM histórico, 2002.

ANPEd, (2002). ANPED 25 anos - Sistemática de avaliação de trabalhos, posters e minicursos. Boletim da Associação Nacional de Pós-graduação e Pesquisa em Educação, n 3 , p. 8. ARAÚJO, Ronaldo M. de L., (1997). As novas “qualidades pessoais" requeridas pelo capital. Trabalho apresentado na $20^{\text {a }}$ Reunião Anual da ANPEd. In: ANPEd 25 anos, CD-ROM histórico, 2002. ARRAIS NETO, Enéas de A., (1999). Educação para uma sociedade de alta qualificação profissional: os equívocos da busca de competitividade sob a nova divisão internacional do trabalho. In: ANPEd - $22^{\text {a }}$ Reunião Anual - Diversidade e desigualdade: desafios para a educação na fronteira do século. Programa e resumos. Caxambu, MG, 26 a 30 de setembro.

AZEVEDO, Janete M.L. de, AGUIAR, Márcia A., (2001). A produção do conhecimento sobre a política educacional no Brasil: um olhar a partir da ANPEd. Educação \& Sociedade, CEDES, Campinas, $\mathrm{n}^{\circ} 77$, p. 49-70, dez.

BAKHTIN, M. (1997). Estética da criação verbal. São Paulo: Martins Fontes.

BIANCHETTI, Lucídio, (1998). As novas tecnologias e a devassagem do espaço-tempo do saber tácito dos trabalhadores. Trabalho apresentado na $21^{\mathrm{a}}$ Reunião Anual da ANPEd. In: ANPEd 25 anos, CD-ROM histórico, 2002.

CASTRO, Ramon P., (1998). Desvalorização real do trabalho e centralidade ilusória da educação. Trabalho apresentado na $21^{\text {a }}$ Reunião Anual da ANPEd. In: ANPEd 25 anos, CD-ROM histórico, 2002.

CÊA, Georgia Sobreira dos Santos, (1999). A relação entre trabalho e educação básica: elementos de um consenso interessado. Trabalho \& Crítica, Anuário do GT Trabalho e Educação, ANPEd/UFF, $n^{\circ} 1$, p. 84-97.

CHARTIER, Roger (org.), (1996). Práticas de leitura. São Paulo: Estação Liberdade.

CODO, Wanderley (org.), (1999). Educação: carinho e trabalho. Petrópolis: Vozes/CNTE/UnB.

CORRÊA, Maria Laetitia, TEIXEIRA, Alessandra L., (2000). Uma nova faceta da gestão empresarial: a conformação da subjetivi- 
dade do trabalhador. Trabalho apresentado na $23^{\text {a }}$ Reunião Anual da ANPEd. In: ANPEd 25 anos, CD-ROM histórico, 2002.

CORRÊA, Vera, (2000). Formação da consciência política dos professores em tempos de globalização e neoliberalismo. Trabalho \& Crítica, Anuário do GT Trabalho e Educação, ANPEd/ UNISINOS, $n^{\circ} 2$, p. 147-160.

DEJOURS, Christhophe, (1992). A loucura do trabalho. Estudo da psicopatologia do trabalho. 5. ed. São Paulo: Cortez/Oboré.

DELUIZ, Neise, (1996). Projetos em disputa: empresários, trabalhadores e formação profissional. Trabalho apresentado na $19^{\text {a }}$ Reunião Anual da ANPEd. In: ANPEd 25 anos, CD-ROM histórico, 2002.

DUARTE, Luiz Fernando D., (1986). Da vida nervosa nas classes trabalhadoras urbanas. Rio de Janeiro: Jorge Zahar; Brasília: CNPq.

FERREIRA, Maria Onete Lopes, (2001). A crise dos referenciais e os pesquisadores em trabalho e educação: o lugar do marxismo entre os educadores. In: ANPEd - $24^{\text {a }}$ Reunião Anual. Programas e resumos. Caxambu, MG, 7 a 11 de outubro. Texto completo disponível em: ANPEd 25 anos, CD-ROM histórico, 2002.

FERREIRA, Norma S.A., (2002). As pesquisas denominadas "estado da arte". Educação \& Sociedade, Campinas, CEDES, n 79 , p. 257-74, ago.

FIDALGO, Fernando, (1999). A formação profissional negociada: França e Brasil, anos 90. Trabalho \& Crítica, GT Trabalho e Educação, ANPEd/UFF, n ${ }^{\circ}$, p. 58-70.

FRANCO, Maria A. Ciavatta, (1998a). Formação profissional para o trabalho incerto: um estudo comparativo Brasil, México e Itália. In: FRIGOTTO, Gaudêncio (org.). Educação e crise do trabalho: perspectivas de final de século. Petrópolis: Vozes, p. 100-137.

, (1998b). Imagens do mundo do trabalho: a fotografia como fonte histórica. Minicurso. In: ANPEd $-21^{\text {a }}$ Reunião Anual - Conhecimento e poder: em defesa da universidade pública. Programas e resumos. Caxambu, MG, 20 a 24 de setembro.

(1990). O trabalho como princípio educativo. Uma investigação teórico-metodológica (1930-1960). Tese de doutorado. Pontifícia Universidade Católica do Rio de Janeiro.

FRANCO, Maria A. Ciavatta, BAETA, Ana Maria B., (1985). Quinze anos de vestibular (1968-1993): apresentação. Educação e Seleção, São Paulo, Fundação Carlos Chagas, $\mathrm{n}^{\circ}$ 12, p. 5-8, jul.-dez.
FRIGOTTO, Gaudêncio, (1998). Educação, crise do trabalho assalariado e desenvolvimento: teorias em conflito. In: (org.). Educação e crise do trabalho: perspectivas de final de século. Petrópolis: Vozes, p. 25-54.

, (2001). A nova e a velha faces da crise do capital e o labirinto dos referenciais teóricos. In: FRIGOTTO, Gaudêncio, CIAVATTA, Maria (orgs.). Teoria e educação no labirinto do capital. Petrópolis: Vozes, p. 23-50.

FURTADO, Celso, (1998). O capitalismo global. 2. ed. São Paulo: Paz e Terra.

GENTILI, Pablo, (1996). La maldición divina? Las complejas relaciones entre los hombres de negocios y las políticas educativas. Trabalho apresentado na $19^{\mathrm{a}}$ Reunião Anual da ANPEd. In: ANPEd 25 anos, CD-ROM histórico, 2002.

, (1997). Educar para o desemprego: a desintegração da promessa integradora. Trabalho apresentado na $20^{\mathrm{a}}$ Reunião Anual da ANPEd. In: ANPEd 25 anos, CD-ROM histórico, 2002. (1998). Educar para o desemprego: a desintegração da promessa integradora. In: FRIGOTTO, Gaudêncio (org.). Educação e crise do trabalho: perspectivas de final de século. Petrópolis: Vozes, p. 76-99.

GOMEZ, Carlos Minayo et al., (1987). Trabalho e conhecimento: dilemas na educação do trabalhador. São Paulo: Cortez e Autores Associados.

HOPSTEIN, Graciela, (1999). Políticas de “capacitación” de los trabajadores públicos en el marco de la reforma del Estado en Argentina (1991-1995): formación profesional o búsqueda de consenso? Trabalho \& Crítica, Anuário do GT Trabalho e Educação, ANPEd/UFF, $n^{\circ}$ 1, p. 43-57.

INVERNIZZI, Noela, (2000). Qualificação e novas formas de controle da força de trabalho no processo de reestruturação da indústria brasileira; tendências dos últimos vinte anos. In: ANPEd - 23 $3^{\mathrm{a}}$ Reunião Anual - Educação não é privilégio (Centenário de Anísio Teixeira). Programas e resumos. Caxambu, MG, 24 a 28 setembro.

KUENZER, Acácia Zeneida, (1987). Educação e trabalho no Brasil ; o estado da questão. Brasília: INEP/MEC.

(1998). Desafios teórico-metodológicos da relação trabalho-educação e o papel social da escola. In: FRIGOTTO, Gaudêncio (org.). Educação e crise do trabalho: perspectivas de final de século. Petrópolis, Vozes.

KUENZER, Acácia et al., (1992). Trabalho e educação. São Paulo: ANDE, ANPEd/Campinas: CEDES, Papirus (Coleção CBE). 
LAUDARES, João Bosco, TOMAS, Antônio, (2002). O técnico de escolaridade média no setor produtivo: seu novo lugar e suas competências. Trabalho \& Crítica, Anuário do GT Trabalho e Educação, ANPEd/UFSC, n 3, p. 255-269.

LEHER, Roberto, (1996). Educação e tempo desiguais: reconstrução da problemática trabalho e educação. In: ANPEd - $19^{\mathrm{a}}$ Reunião Anual - A política de educação no Brasil: globalização e exclusão social. Programas. Caxambu, MG, 22 a 26 de setembro.

, (1999). Para fazer frente ao apartheid educacional imposto pelo Banco Mundial: notas para uma leitura da temática trabalho-educação. Trabalho \& Crítica, Anuário do GT Trabalho e Educação, ANPEd/UFF, n 1, p. 16-29.

MACÁRIO, Epitácio, (2001). Determinações ontológicas da educação: uma leitura à luz da categoria trabalho. In: ANPEd - $24^{\text {a }}$ Reunião Anual - Intelectuais, conhecimento e espaço público. Programas e resumos. Caxambu, MG, 7 a 11 de outubro.

MARKERT, Werner, (1997). Trabalho em grupo nas empresas alemãs: um novo modelo de produção e uma proposta conceitual de formação profissional. Trabalho apresentado na $22^{\mathrm{a}}$ Reunião Anual da ANPEd. In: ANPEd 25 anos, CD-ROM histórico, 2002.

, (2000). Novas competências no mundo do trabalho e suas contribuições para a formação do trabalhador. In: ANPEd - 23 $3^{\text {a }}$ Reunião Anual - Educação não é privilégio (Centenário de Anísio Teixeira). Programas e resumos. Caxambu, MG, 24 a 28 de setembro. Texto completo disponível em: ANPEd 25 anos, CD-ROM histórico, 2002.

, (2001). Trabalho, universidade, comunicação e sensibilidade - aspectos teórico-metodológicos para um conselho dialético de competência. In: ANPEd - $24^{a}$ Reunião Anual da ANPEd - Intelectuais, conhecimento e espaço público. Programas e resumos. Caxambu, MG, 7 a 11 de outubro. Texto completo disponível em: ANPEd 25 anos, CD-ROM histórico, 2002.

MARTINS, Herbert Gomes, (1997). A qualidade total como confirmação do campo pedagógico através da aprendizagem organizada: o caso da Companhia Cervejaria Brahma-RJ. In: ANPEd - 20ª Reunião Anual - Educação, crise e mudança: tensões entre a pesquisa e a política. Programas e resumos. Caxambu, MG, 21 a 25 de setembro.

MORAES, Carmen Sylvia Vidigal de, FRANCO, Maria Ciavatta (1999). Trabalho e Educação na sociedade brasileira: uma perspectiva histórica. Minicurso. In: ANPEd - $22^{\mathrm{a}}$ Reunião Anual - Diversidade e desigualdade: desafios para a educação na fronteira do século: Programas e resumos. Caxambu, $\mathrm{MG}$, 26 a 30 de setembro, p. 27.

NOGUEIRA, Paulo H., (2001). Habermas e a não centralidade formativa do trabalho, uma crítica filosófica ao marxismo. In: ANPEd - 24 a Reunião Anual - Intelectuais, conhecimento e espaço público. Programas e resumos. Caxambu, MG, 7 a 11 de outubro.

NOSELLA, Paolo, BUFFA, Esther, (1995). Escolástica ou historicismo? In: ANPEd 25 anos, CD-ROM histórico, 2002. , (1997). Artes liberais e mecânicas: a difícil integração. In: ANPEd - 20 ${ }^{\mathrm{a}}$ Reunião Anual - Educação, crise e mudança: tensões entre a pesquisa e a política. Programa $e$ resumos. Caxambu, MG, 23 a 25 de setembro.

OSOWSKI, Cecília, MARTINI, Jussara Gue, (1996). Trabalhadores infanto-juvenis de escolas de primeiro grau; contribuindo para repensar o currículo. ANPEd, GT Trabalho e Educação. In: ANPEd 25 anos, CD-ROM histórico, 2002.

PALANGANA, Isilda C., (1998). Individualidade: afirmação e negação na sociedade capitalista. In: ANPEd $-21^{\mathrm{a}}$ Reunião Anual Conhecimento e poder: em defesa da universidade pública. Programas e resumos. Caxambu, MG, 20 a 24 de setembro.

PORTELA, Josania L., (2000). Relação: educação, trabalho e cidadania. In: ANPEd - 23 $3^{a}$ Reunião Anual - Educação não é privilégio (Centenário de Anísio Teixeira). Programas e resumos. Caxambu, MG, 24 a 28 de setembro.

RAMOS, Marise N., (1996). Reforma da educação profissional: uma síntese contraditória da (a)diversidade estrutural. Trabalho apresentado na $19^{\text {a }}$ Reunião Anual da ANPEd. In: ANPEd 25 anos, CD-ROM histórico, 2002.

REBOUÇAS, Antonio José de Arruda, (1989). Insalubridade: morte lenta no trabalho. São Paulo: Oboré.

RESENDE, Anita C. Azevedo, (1999). Subjetividade e trabalho ou subjetividade não é cognição. Trabalho \& Crítica, Anuário do GT Trabalho e Educação, ANPEd/UFF, n 1, p. 160-172.

RODRIGUES, José, (1998). Pensamento pedagógico industrial. Trabalho apresentado na $21^{\text {a }}$ Reunião Anual da ANPEd. In: ANPEd 25 anos, CD-ROM histórico, 2002.

RUMMERT, Sonia M., (1998). Capital e trabalho: convergências e divergências quanto à educação básica. Trabalho apresentado na $21^{\text {a }}$ Reunião Anual da ANPEd. In: ANPEd 25 anos, CDROM histórico, 2002. 
SANTOS, Eloisa Helena, (1996). O saber em trabalho: a experiência de desenvolvimento tecnológico pelos trabalhadores de uma indústria brasileira. Trabalho apresentado na $19^{a}$ Reunião Anual da ANPEd. In: ANPEd 25 anos, CD-ROM histórico, 2002.

SANTOS, Aparecida de Fátima Tiradentes dos, (2002). O novo ensino médio agora é para a vida: neoliberalismo, racionalidade instrumental e a relação trabalho-educação na reforma do ensino secundário. Trabalho \& Crítica, Anuário do GT Trabalho e Educação, ANPEd/UFSC, n 3, p. 217-233.

SHIROMA, Eneida, CAMPOS, Roselane F., (1997). Qualificação e reestruturação produtiva: um balanço das pesquisas em educação. Educação \& Sociedade, Campinas, CEDES, $n^{\circ}$ 61, p. 13-35, dez.

SILVA, Tomaz Tadeu da (org.), (1991). Trabalho, educação e prática social: por uma teoria da formação humana. Porto Alegre: Artes Médicas.

SILVA, Maria Vieira, (2002). O ethos empresarial na educação escolar: novos dispositivos, novas subjetividades. Trabalho \& Crítica, Anuário do GT Trabalho e Educação, ANPEd/UFSC, n 3 , p. 183-199.

SOARES, Suely Galli, (1999). Qualificação: o mito da integração social. Políticas públicas e educação profissional no Estado de São Paulo: aspectos inovadores e prontos críticos. Trabalho \& Crítica, Anuário do GT Trabalho e Educação, ANPEd/UFF, $\mathrm{n}^{\circ} 1$, p. $71-83$.

SOUZA, Donaldo B. de, SANTANA, Marco Aurélio, DELUIZ, Neise, (1999). O entendimento da CUT, CGT e FS sobre o papel da educação face às transformações no mundo do trabalho: tensões e dinâmicas estruturais e conjunturais. Trabalho apresentado na $22^{\mathrm{a}}$ Reunião Anual da ANPEd. In: ANPEd 25 anos, CD-Rom histórico, 2002.

SOUZA, Maria das Graças Galvão, (1997). A complementação de escolaridade do trabalhador na empresa: uma experiência baiana. Trabalho apresentado na $20^{\mathrm{a}}$ Reunião Anual da ANPEd. In: ANPEd 25 anos, CD-ROM histórico, 2002.

TOMAS, Antônio, LAUDARES, João Bosco, (2002). O técnico de escolaridade média no setor produtivo: seu novo lugar e suas competências. Trabalho \& Crítica, Anuário do GT Trabalho e Educação, ANPEd/UFSC, n 3, p. 255-270.
TREIN, Eunice, (1996a). Entrevista. Revista do NETE, UFMG, $\mathrm{n}^{\circ}$ 0, p. 32-40, jul.-dez.

, (1996b). A pesquisa na área trabalho e educação. Curitiba: UFPR (mimeo.).

(1998). Trabalho e educação diante dos limites da globalização: questões teórico-metodológicas. Revista do NETE, UFMG, n 3, p. 119-128, jan.-jul.

TREIN, Eunice, PICANÇO, Iracy S., (1995). O GT Trabalho e Educação. In: Histórico dos grupos de trabalho. Belo Horizonte: ANPEd.

TUMOLO, Paulo Sérgio, (1996). A educação frente às metamorfoses do mundo do trabalho: uma proposta de método de análise. Trabalho apresentado na $19^{\mathrm{a}}$ Reunião Anual da ANPEd. In: ANPEd 25 anos, CD-ROM histórico, 2002.

, (1997). O novo padrão de acumulação do capital e a formação sindical da Central Única dos Trabalhadores. Trabalho apresentado na $20^{\mathrm{a}}$ Reunião Anual da ANPEd. In:ANPEd 25 anos, CD-ROM histórico, 2002.

(1998). Reestruturação produtiva no Brasil: um balanço crítico da produção bibliográfica. Trabalho apresentado na $21^{\text {a }}$ Reunião Anual da ANPEd. In: ANPEd 25 anos, CDROM histórico, 2002.

(2000). Da subsunção formal do trabalho à subsunção real da vida social ao capital: apontamentos de interpretação do capitalismo contemporâneo. Trabalho \& Crítica, Anuário do GT Trabalho e Educação, ANPEd/UNISINOS, $\mathrm{n}^{\circ} 2$, p. $15-30$.

WITTMANN, Lauro C., GRACINDO, Regina V. (orgs.), (2001). O estado da arte em política e gestão da educação no Brasil, 1991-1997. Campinas: ANPAE/Autores Associados.

ZIBAS, Dagmar, (1996). O reverso da medalha: os limites da administração industrial participativa (um estudo de caso). Trabalho apresentado na $19^{\mathrm{a}}$ Reunião Anual da ANPEd. In: ANPEd 25 anos, CD-ROM histórico, 2002.

Recebido em abril de 2003 Aprovado em julho de 2003 